PERIODICALS OF ENGINEERING AND NATURAL SCIENCES

Vol. 5 No. 1 (2017) - Special Issue (Recent Topics in Environmental Science)

Available online at: http://pen.ius.edu.ba

\title{
Usage of Fly Ash and Waste Slime Boron for Soil Stabilization
}

\author{
İsmail ZORLUER \\ Afyon Kocatepe University, Faculty of Engineering, Department of Civil \\ Engineering, Afyonkarahisar, Turkey.
}

\author{
Süleyman GÜCEK \\ Afyon Kocatepe University, Dazkırı Vocational High School, Dazkırı, \\ Afyonkarahisar, Turkey.
}

\begin{abstract}
Waste materials are hazardous and serious problem for environment. Because, they occur soil pollution, ground water pollution and also visual pollution. Especially, industrial wastes are composed in large quantities. Many scientists have made research to solve these problems. According to their results, they have suggested that usage of waste materials in many areas as a material or additive material. One of the areas is soil stabilization. Soil properties are improved with this additive wastes. In this study, laboratory tests were conducted on granular soil specimens amended with fly ash and slime waste boron. The specimens were prepared with granular soil and fly ash-waste boron at different ratios. They were compacted standard Proctor compaction energy and, than were cured 1, 7 and 28 days. After cure unconfined compressive tests were conducted to investigate the effect of fly ashwaste boron on granular soil strength. Addition of fly ash-waste boron increased soil strength. As a result, fly ashwaste boron can be used with granular soil for increasing strength. This is economical solution.
\end{abstract}

Keywords: Fly ash, Waste slime boron, Soil stabilization

\section{Introduction}

Waste materials are serious environmental problem because they have harmed to soil, ground water and also have formed visual pollution. Rapidly developing technology has increased production and consumption. This situation has increased energy needs too at the same way. The increasing of production and consumption results in the increase of amount of waste. Especially industrial wastes are formed serious problem due to very large quantities. In the developing countries, distinct rules of waste disposing are initiated to prevent the environment pollution. Also, many scientists research about usability of wastes in many areas. This case is positive effects on environment by means of recycling, regains to economy and reducing environmental pollution. Wastes materials were began to be used in soil stabilization like usage in many areas. Because these waste materials increases some parameters of soil like strength and decreases some parameters like settlement, permeability.

Borax is a highly soluble material and increases viscosity, toughness and strength in many materials and reduces the radiation, sound, thermal permeability. For this reason, boron products are used in many areas such as glass, drug, paint, airplane, ceramic industry, agriculture, metallurgy, nuclear applications, glaze and enameled coatings, steel and space industries, automotive industry, rocket fuel, capsule, radiation preventive sheaths, fire extinguishers, radio tube[1].

Turkey is a rich country with regards of boron reserve and has met $40-50 \%$ of World consumption. Total of annual raw material production is approximately 1.3 million tons in Turkey. With this production, a serious solid/liquid waste problem was revealed. Solid wastes are discarded in the open area, and liquid wastes are collected in dams [1].

Fly ash is the main by-products of coal combustion for electrical energy production. Fly ash is one of the waste materials that are generated by the coal industry in very large quantities. However, a small part $(25 \%-30 \%)$ of the fly ash can be used in many areas. Its utilization is not limited and it is added to cement and concrete products, construction materials as a light weight aggregate, infiltration barrier, underground, void filling, water and environmental improvement, and is used in geotechnical stabilization as an additive material, structural fill, cover material, unpaved roads, highway base structures, roadway and pavement etc. There are a lot of studies about fly ash used in the stabilization of soils. In the previous studies [2, 3, 4, 5, 6, 7] it was indicated that the engineering properties of fly ash amended soils have been improved. Generally, fly ash was used together with different additive materials like 
cement, lime or industrial wastes like marble dust, cement kiln dust, etc.

On the other hand, boron compounds in this waste discharged to land dissolved by rain water, and pass to soil where they form some complexes with heavy metals such as $\mathrm{Pb}, \mathrm{Cu}, \mathrm{Co}, \mathrm{Ni}, \mathrm{Cd}$, etc., so that the potential toxicity of these metals increases, and cause some serious health and environmental problems when the complexes pass to groundwater. Hence, there is a necessity of making use of this waste in large amount to avoid the environmental problems [1]. Fly ash is an important material for various applications. The utilization of fly ash in construction, removal of organic compounds, heavy metals, dyes, and zeolite synthesis can help a great deal in the reduction of environmental pollution. The unburned carbon in fly ash plays an important role for adsorption [8]. When fly ash is used together with waste materials, it is expected to reduce harmful effects of these waste materials.

In this study, laboratory tests will be conducted on granular soil specimens amended with fly ash and slime waste boron. The specimens will be prepared with granular soil and fly ash-waste slime boron at different ratios. They will be compacted standard Proctor compaction energy and, than will be cured 1, 7 and 28 days. After curing, unconfined compressive tests will be conducted to investigate the effect of fly ash-waste boron on granular soil strength.

\section{Material and Method}

The granular soil (SG) used in this study was obtained from Afyonkarahisar Municipality, Turkey. This material was used in road construction. It had $23 \%$ particles passing the US No. 10 sieve $(<2 \mathrm{~mm}), 5 \%$ passing US No. 200 sieve $(<0.075 \mathrm{~mm})$. Unit weight is $18.9 \mathrm{kN} / \mathrm{m}^{3}$. It was classified as well graded gravel (GW) according to the Unified Soil Classification System (USCS) and A-1 according to the American Association of State Highway and Transportation Officials (AASHTO).

A-1 class material is a good subbase material in the ASSHTO standards. Some chemical compounds of the granular soil are shown in Table 1. The waste slime boron used in this study was obtained from Etibor Kırka Borax Company in Eskişehir, Turkey. Waste boron was dried and sieved from sieve \#40, resulting in waste boron grains that are smaller than $425 \mu \mathrm{m}$. Some chemical compounds of the waste slime boron are shown in Table 1. The fly ash was obtained from SomaB Power Plant in Manisa, Turkey. It is F class according to ASTM C 618 [9] and W class according to TS EN 197-1 standard [10]. Approximately, $80 \%$ of the particles are finer than the U.S. No. 200 sieve size.
Some chemical compounds of the waste fly ash are shown in Table 1.

Table 1. Chemical compounds of used materials (\%).

\begin{tabular}{|c|c|c|c|}
\hline & $\begin{array}{l}\text { Waste } \\
\text { boron }\end{array}$ & Fly ash & SG \\
\hline $\mathrm{SiO}_{2}$ & 21.64 & 48.28 & 0.24 \\
\hline $\mathrm{Fe}_{2} \mathrm{O}_{3}$ & 0.19 & 7.19 & 0.06 \\
\hline $\mathrm{Al}_{2} \mathrm{O}_{3}$ & 0.75 & 27.72 & 0.16 \\
\hline $\mathrm{CaO}$ & - & 10.51 & 36.05 \\
\hline MgO & 9.40 & 2.51 & 16.99 \\
\hline $\mathrm{SO}_{3}$ & - & 3.16 & - \\
\hline $\mathbf{P}_{2} \mathbf{O}_{5}$ & - & 0.27 & - \\
\hline $\mathbf{T i}_{2} \mathbf{O}_{2}$ & 16.77 & 1.28 & 0.01 \\
\hline $\mathrm{Na}_{2} \mathrm{O}$ & 7.88 & - & - \\
\hline $\mathbf{B}_{2} \mathbf{O}_{2}$ & 7.75 & - & - \\
\hline LOI & 35.38 & - & 46.40 \\
\hline
\end{tabular}

Identification tests were performed according to TS 1900-1[11] standard. The distribution of the particle sizes was determined by sieving. For the sieve analysis, the granular soil was washed above the $0.075-\mathrm{mm}$ sieve and dried in the drying oven. Then, it was sieved by a sieve set. For the standard and modified compaction tests, water was added to the dried granular soil material and mixed. The wet specimen was compacted in the compaction mold (diameter: $105 \mathrm{~mm}$ height: $115.5 \mathrm{~mm})$. For the standard Proctor test, the compaction process was performed in three layers of approximately equal mass, each layer being given 25 blows from $2.5 \mathrm{~kg}$ rammer dropped from a height of $305 \mathrm{~mm}$ above the specimen. The maximum dry density and optimum water content were determined from the relationships between the dry density and the water content of these processes for every test separately. For the sample preparation, the granular soil was mixed with waste slime boron and fly ash at three different ratios and the dry weights of the materials were used for the mixtures. The percentage of additives was obtained from literature [5, 6, 8]. All of the specimens were compacted with standard Proctor compaction energies and optimum water contents. The compositions of the mixtures and the compaction characteristics are given in Table 2.

Table 2. Mixing Ratio and Compaction Characteristics of Specimens

\begin{tabular}{llcc}
\hline & Mixing ratio & $\boldsymbol{\rho}_{\mathbf{d m a x}}\left(\mathbf{k N} / \mathbf{m}^{\mathbf{2}}\right)$ & $\mathbf{w}_{\text {opt }}(\boldsymbol{\%})$ \\
\hline SG & & 2,19 & 7,5 \\
5BR-10FA & SG+5\% Boron + 10\% Fly ash & 2,09 & 8,1 \\
10BR-20FA & SG+10\% Boron + 20\% Fly ash & 2,00 & 9,9 \\
15BR-30FA & SG+15\% Boron + 30\% Fly ash & 1,92 & 10,1 \\
\hline
\end{tabular}

$\mathrm{pH}$ and Electrical Conductivity (EC) values of specimens were measured. For this test, dried specimens were sieved with No: $10^{\#}$ sieve $(2 \mathrm{~mm}) .10 \mathrm{~g}$ were weighed, then $50 \mathrm{~mL}$ distilled water were added and were mixed with specimens. After 1 hour, 
measurements were performed. $\mathrm{pH}$ and Electrical Conductivity (EC) values of specimens are given in Table 3. After 24 hours and 96 hours, to see effects of additives and changes, measurements were performed again.

Table 3. pH and Electrical Conductivity (EC) values of specimens

\begin{tabular}{lrrrrrrr}
\hline & \multicolumn{3}{c}{$\mathbf{p H}$} & \multicolumn{3}{c}{$\mathbf{E C}(\boldsymbol{\mu} \mathbf{S} / \mathbf{c m})$} \\
& $\mathbf{1 ~ h}$ & $\mathbf{2 4} \mathbf{~ h}$ & $\mathbf{9 6} \mathbf{h}$ & $\mathbf{1 h}$ & $\mathbf{2 4} \mathbf{~ h}$ & $\mathbf{9 6 h}$ \\
\hline SG & 8,50 & 8,65 & 8,60 & 870 & 810 & 770 \\
5BR-10FA & 11,99 & 12,12 & 12,32 & 2443 & 2132 & 2142 \\
10BR-20FA & 12,16 & 12,14 & 12,39 & 2523 & 2154 & 2172 \\
15BR-30FA & 12,35 & 12,20 & 12,31 & 2616 & 2167 & 2136 \\
\hline
\end{tabular}

\subsection{Unconfined compressive strength test}

The unconfined compressive strength $\left(\mathrm{q}_{\mathrm{u}}\right)$ is a measure of the strength of the mixtures. It shows the effects of the additive materials to granular soil strength. The unconfined compressive strength test followed the procedures outlined in the TS 1900-2 standard [12]. A strain rate of $1 \% / \mathrm{min}$ was maintained during this test. The specimens that were mixed with the granular soil, waste slime boron and fly ash, were compacted in a standard Proctor mold. After compaction, the specimens were extruded with a hydraulic jack from the compaction mold. Two specimens were prepared from this mold separately for a mixture ratio. The specimens were sealed in a plastic wrap three times and covered with a wet cloth for controlling humidity. The cloth was wetted every day, and then, the specimens were cured 1,7 , and 28 days. Duplicated specimens were tested for the unconfined compressive test as quality control, and the averages of these two tests were reported as the results.

\section{Results and discussion}

The effects of the additive materials on the optimum water content and the maximum dry density are given in Table 2. The results show that the addition of additives causes an increase in the optimum water content and a decrease in max. dry density. The reason for the increase in the optimum water content is an increase in the particle surface area of samples due to the addition of finer materials. Similar trends have been obtained from some experimental works $[3,4,5,6,7]$.

$\mathrm{pH}$ and EC test results indicate that additive materials increased values of $\mathrm{pH}$ and EC. This can be seen in Table 3. The $\mathrm{pH}$ increased from about 8,5 to about 12,0. EC values increased from $870 \mu \mathrm{S} / \mathrm{cm}$ to between $2443 \mu \mathrm{S} / \mathrm{cm}$ and $2616 \mu \mathrm{S} / \mathrm{cm}$, depending on increase of additive. But, $\mathrm{pH}$ did not change much with increase additive material after from first additive. When time dependent effect of additive was observed, $\mathrm{pH}$ did not change much, EC decreased. At the end of 24 hours and
96 hours, EC values decreased to approximately 2130 $2170 \mu \mathrm{S} / \mathrm{cm}$. Furthermore, 15BR-30FA mixture was more effective than 5BR-10FA and 10BR-20FA for EC. Because EC value decreased from $2616 \mu \mathrm{S} / \mathrm{cm}(24$ hours) to $2136 \mu \mathrm{S} / \mathrm{cm}$ at the end of 96 hours.

Unconfined compressive test results can be seen in figure 1, 2 and table 4 . The strength increased in all specimens with the increase in additive amount. The highest strength values were obtained as $1438 \mathrm{kPa}$ in 15BR-30FA mixture ratio. Similar situations were seen in the cure time increase. The strength values increase in the cure time in all the specimens. The increases were shown linear trend, but the strength of specimens with 15BR-30FA increased too much at the end of 28 day cure. Actually, in 1-day cure and 7-day cure, strength values of specimen with 15BR-30FA are less than strength values of specimen with 10BR-20FA. According to1-day cure and 7-day cure, optimum mixing ratio is 10BR-20FA because of higher strength values. Despite of the highest strength in the specimen with15BR-30FA after 28-day cure.

Table 4. Unconfined compression test results $\left(\mathrm{kN} / \mathrm{m}^{2}\right)$

\begin{tabular}{lccc}
\hline & 1 Day & 7 Day & 28 Day \\
\hline SG & 144,5 & 307,8 & 410,6 \\
5BR-10FA & 356,6 & 481,0 & 607,1 \\
10BR-20FA & 497,2 & 672,0 & 748,0 \\
15BR-30FA & 434,6 & 593,5 & 1438,0 \\
\hline
\end{tabular}

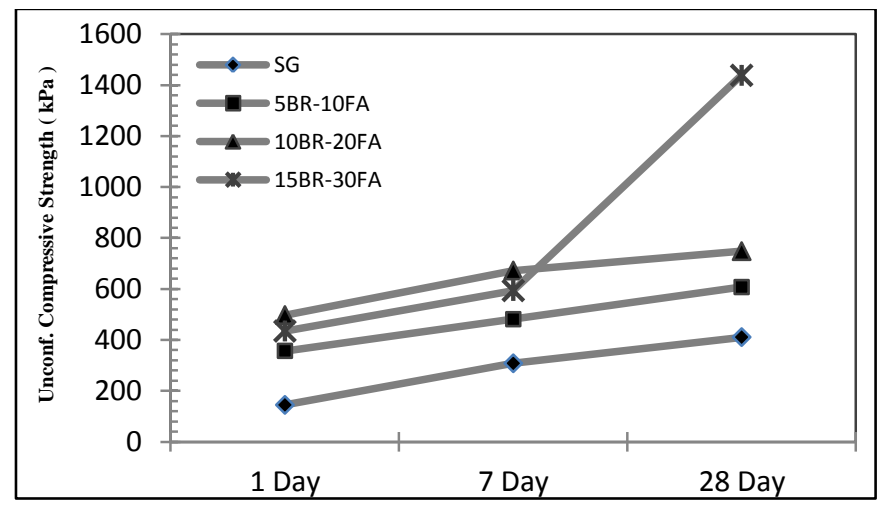

Figure 1. Unconfined compressive strength-cure time

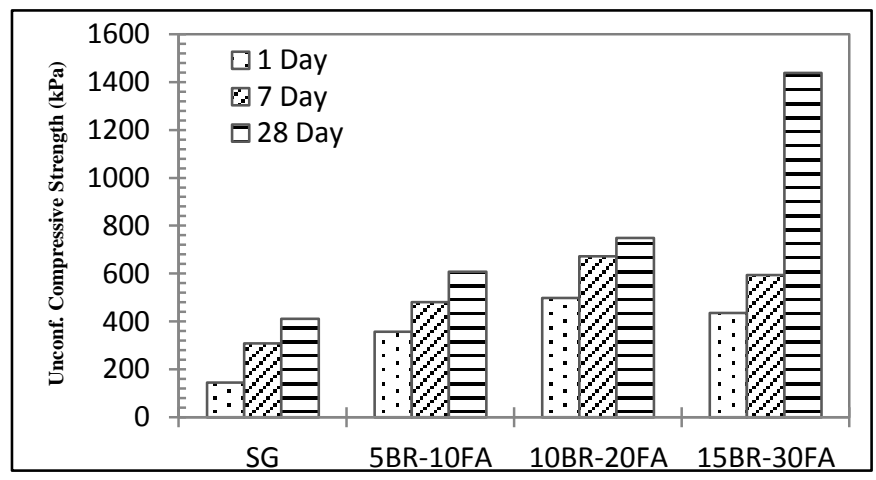

Figure 2. Unconfined compressive strength - additive ratio 
Mostly these increases can be caused by fly ash, because there are a lot studies about fly ash in soil stabilization. And it is not also well known effect of boron to soil stabilization. But strength results are shown that boron is useable in soil stabilization. Boron waste should be used to reduce wastes in many areas.

Otherwise, heavy metals in the boron wastes are serious problem for ground water and soils [1]. When waste boron and fly ash are used together, fly ash can help to decrease this problem by absorption properties. The unburned carbon in fly ash plays an important role for adsorption [8]. Heavy metals are absorbed by fly ash, soil and ground water are protected from contaminant. However, it should be made chemical analyses to measure absorption capacity of fly ash.

\section{Conclusions}

Recycling of industrial waste is beneficial environmentally and economically. In economic terms, it is cheap, and in environmental terms, it decreases pollution. In this study, it is investigated the beneficial reuse of waste boron and fly ash in soil stabilization. Tests were performed on granular soil mixtures amended with waste boron and fly ash. $\mathrm{pH}$ and EC values measured in all mixtures. For unconfined compression tests, specimens were prepared with standard Proctor compaction energy and, than were cured 1,7 and 28 days. Then, unconfined compressive strength tests were performed after cure time in these specimens. Waste boron and fly ash can be used as an additive material in soil stabilization. 10BR-20FA can be explained as a suitable mixing ratio. It should be made other chemical analyses on waste boron-fly ash mixtures and the impact of these wastes on soil and ground water should be investigated.

\section{Acknowledgements}

This study was supported from Commission of Scientific Research Projects (AKÜ-BAP) with the project, 16.KARIYER.47.

\section{References}

[1] Koyuncu H. Güney Y. Stabilization of borax wastes. First International Conference on Environmental Research and Assessment. Bucharest, Romania, March 23-27, 2003

[2] Arora S, Aydilek AH. Class F Fly-Ash-Amended Soils as Highway Base Materials Journal of Materials in Civil Engineering. 2005, 17, 640 - 649.

[3] Cetin B, Aydilek AH, Guney Y. Stabilization of recycled base materials with high carbon fly ash. Resources, Conservation and Recycling, 2010. 54,87854,892 .
[4] Vishwanathan R. Saylak D. Estakhri E. Stabilization of subgrade soils using fly ash. Ash Utilization Symposium. CAER. Kentucky. 1997. 204 211.

[5] Fauzi A, Nazmi WM, Fauzi UJ. Engineering Quality Improvement of Kuantan Clay Subgrade using Recycling and Reused Materials as Stabilizer. In The 3rd International Conference on Geotechnical Engineering for Disaster Mitigation and Rehabilitation (GEDMAR 2011). Semerang, Indonesia. 2011. 500506.

[6] Zorluer I. Demirbas A. Use of marble dust and fly ash in stabilization of base material. Science and Engineering of Composite Materials. 2013. 20(1). 4755

[7] Zorluer I. Gucek S. The effects of marble dust and fly ash on clay soil. Science and Engineering of Composite Materials. 2014. 21(1). 59-67.

[8] Ahmaruzzaman M. A review on the utilization of fly ash Progress in Energy and Combustion Science. 36. 2010. 327-363.

[9] ASTM C 618. Standard specification for coal fly ash and raw or calcined natural pozzolan for use in concrete. Annual Book of ASTM Standards. 2003.

[10] TS EN 197-1. (Turkish Standard) Cement - Part 1: Generally cements-compounds, properties and convenient criteria. 2002.

[11] TS 1900-1 (Turkish Standard). Methods of testing soils for civil engineering purposes in the laboratory Part 1: Determination of physical properties. 2006.

[12] TS 1900-2. (Turkish Standard). Methods of testing soils for civil engineering purposes in the laboratory Part 2: Determination of mechanical properties. 2006. 